A, et al. Thorax 2010;65:4. A33), the determinants of the length of NIV have not been clearly elucidated, which we decided to investigate.

Methods A retrospective analysis of the initial ABG values on 67 episodes of NIV for COPD at a dedicated respiratory NIV unit from 1 November 2010 to 30 June 2011 was carried out. Analysis of blood gases and duration of use of NIV was documented and analysed.

Results In an 8-month period, 67 patients were admitted to the NIV unit with AHRF with COPD. There were 6 (8.95\%) in-hospital deaths in this group. Mean (range) $\mathrm{pH}$ on admission was 7.26 (7.08-7.34), mean (range) $\mathrm{pCO}_{2}$ was $9.75 \mathrm{kPa}$ (6.03-15.5), mean (range) arterial bicarbonate level $\left(\mathrm{HCO}_{3}\right) 27.2 \mathrm{mmol} / 1$ (19.9-45.2). The mean peak Inspiratory Positive Airway Pressure (IPAP) used was $18.7 \mathrm{~cm} \mathrm{H}_{2} \mathrm{O}$ and peak Expiratory Positive Airway Pressure (EPAP) was $5.4 \mathrm{~cm} \mathrm{H}_{2} \mathrm{O}$. Plotting a graph with $\mathrm{HCO}_{3}$ and length of NIV we see that it has a linear relationship (see Abstract P267 figure 1). Length of NIV increases by 0.294 days for every $1 \mathrm{mmol} / 1$ increase in $\mathrm{HCO}_{3}$ above the mean.

Discussion This scientific survey indicates that the length of NIV therapy in COPD patients in AHRF increases with a higher $\mathrm{HCO}_{3}$. Though outcome and mortality is closely linked to the $\mathrm{pH}$, length of NIV is more closely linked to the $\mathrm{HCO}_{3}$. This is explained by the fact that people with higher $\mathrm{HCO}_{3}$ are likely to have had chronic respiratory failure for longer and likely to take longer to recover from the respiratory failure.

\section{P268 CAN WE IMPROVE "DOOR-TO-MASK" TIMES FOR PATIENTS WITH CHRONIC OBSTRUCTIVE PULMONARY DISEASE (COPD) REQUIRING NON-INVASIVE VENTILATION (NIV)?}

doi:10.1136/thoraxjnl-2011-201054c.268

${ }^{1} S$ Mandal, ${ }^{1} \mathrm{~T}$ O Howes, ${ }^{2} \mathrm{C} \mathrm{M}$ Roberts. ${ }^{1}$ Colchester University Hospital Trust, Colchester, UK; ${ }^{2}$ Barts and the London School of Medicine and Dentistry, Queen Mary University of London, London, UK

Introduction COPD is a leading cause of mortality and morbidity and timely use of NIV improves outcomes. National guidelines recommend early intervention in persisting acidosis however, audit data suggests that many patients receive NIV late and have high mortality compared to the results of RCTs. We aimed to improve the process of care for these patients through the introduction of a prospective proforma, prompting clinicians to follow guideline recommendations about timely intervention.

Methods The proforma included items that prompted: care in medications being given, $\mathrm{ABGs}$ being taken and decisions regarding escalation of care and resuscitation status being made. All emergency COPD exacerbations managed with NIV were included in the study. Data were collected prospectively for 7.5 months in seven Acute Trusts in London and Essex. Each site was given real time feedback on their performance on a monthly basis.

Results The proforma was used in 138 acidotic COPD patients managed with NIV. Combined data from all the involved sites demonstrated no significant improvement in door-to-mask times during the study period. Overall only $47 \%$ of patients received NIV within $3 \mathrm{~h}$ of admission and there was significant variation between individual sites in door-to-mask times ( $p=0.0007$, Abstract P268 table 1). Sites were grouped according to their respiratory on call system. Sites with a 9-5 respiratory on call had the shortest door-to-mask time, both during 9:00-17:00 and out of hours, mean time $=203.5 \mathrm{~min}$ (SD 259), vs $291.9 \mathrm{~min}$ (SD 231.9) for $24 \mathrm{~h}$ respiratory on call and $327 \mathrm{~min}$ (SD 314.7) for those without a respiratory on call. Patients who were started on NIV in locations outside A\&E had longer mean door to-mask-times (135.62 vs $377.44 \mathrm{~min})$.
Abstract P268 Table 1 Mean door-to-mask times for individual sites

\begin{tabular}{|c|c|c|c|c|c|c|c|}
\hline $\begin{array}{l}\text { On call system } \\
N=\end{array}$ & $\begin{array}{l}\text { Site } 1 \\
9-5 \\
15\end{array}$ & $\begin{array}{l}\text { Site } 2 \\
\text { No On call } \\
24\end{array}$ & $\begin{array}{l}\text { Site } 3 \\
\text { No On call } \\
21\end{array}$ & $\begin{array}{l}\text { Site } 4 \\
9-5 \\
8\end{array}$ & $\begin{array}{l}\text { Site } 5 \\
24 \mathrm{~h} \\
16\end{array}$ & $\begin{array}{l}\text { Site } 6 \\
24 \mathrm{~h} \\
33\end{array}$ & $\begin{array}{l}\text { Site } 7 \\
9-5 \\
18\end{array}$ \\
\hline $\begin{array}{l}\text { Minimum (time in } \\
\text { minutes) }\end{array}$ & 50.0 & 28.0 & 5.0 & 24.0 & 40.0 & 7.0 & 27.0 \\
\hline $\begin{array}{l}\text { Median (time in } \\
\text { minutes) }\end{array}$ & 150.0 & 220.5 & 168.0 & 102.5 & 154.5 & 300.0 & 90.0 \\
\hline $\begin{array}{l}\text { Maximum (time in } \\
\text { minutes) }\end{array}$ & 305.0 & 1440 & 1091 & 261.0 & 362.0 & 1050 & 1440 \\
\hline $\begin{array}{l}\text { Mean (time in } \\
\text { minutes) }\end{array}$ & 157.7 & 391.9 & 252.9 & 133.5 & 146.3 & 362.4 & 272.9 \\
\hline SD & 78.58 & 360.1 & 240.8 & 92.63 & 85.55 & 248.0 & 374.1 \\
\hline SE & 20.29 & 73.50 & 52.54 & 32.75 & 21.39 & 43.17 & 88.17 \\
\hline Lower $95 \% \mathrm{Cl}$ & 114.2 & 239.9 & 143.3 & 56.05 & 100.7 & 274.5 & 86.85 \\
\hline Upper $95 \% \mathrm{Cl}$ & 201.2 & 544.0 & 362.4 & 210.9 & 191.9 & 450.4 & 458.9 \\
\hline
\end{tabular}

Conclusion The introduction of a proforma with monthly feedback reports did not improve door-to-mask times. Less than half the patients managed with NIV received this within $3 \mathrm{~h}$. There remains an unacceptable variation in the standard of patient care that may result from different operational practices across hospitals. There is a need to define optimal service delivery to ensure that all patients receive best care regardless of their place of admission.

\section{P269 FEASIBILITY AND ACCEPTABILITY OF NON-INVASIVE VENTILATION (NIV) AS AN AID TO EXERCISE IN PATIENTS ADMITTED WITH ACUTE EXACERBATION OF CHRONIC RESPIRATORY DISEASE}

doi:10.1136/thoraxjnl-2011-201054c.269

F Dyer, F Bazari, C Jolley, L Flude, V Lord, M I Polkey, N S Hopkinson. NIHR Respiratory Disease Biomedical Research Unit at the Royal Brompton and Harefield NHS Foundation Trust and Imperial College, London, UK

Introduction Patients with acute exacerbations of chronic respiratory disease are often too breathless to exercise, leading to muscle deconditioning. Using NIV to assist exercise during an exacerbation might prevent this, but it is not known if this is acceptable to patients.

Methods 12 in-patients with an acute exacerbation (including Bronchiectasis and CF) were recruited. If they were unable to cycle for $5 \mathrm{~min}$ at 20 Watts unassisted they then cycled with NIV for up to $20 \mathrm{~min}$. NIV settings were adjusted to patient comfort. Patients were asked to rate their level of distress and willingness to repeat the intervention.

Abstract P269 Table 1 Times cycled and change in parameters with exercise

\begin{tabular}{lccll}
\hline & Without NIV & With NIV & Difference (95\% CI) & p Value* \\
\hline Time cycled (s) & $184.42(65.22)$ & $331.08(229.09)$ & $146.47(7.70$ to 285.62) & $0.04^{*}$ \\
Resting $\mathrm{SpO}_{2}$ & $94.83(2.17)$ & $94.83(2.55)$ & $0.0(-1.92$ to 1.92) & $1.00^{*}$ \\
Resting HR & $94.33(16.99)$ & $93.83(18.45)$ & $0.5(-5.75$ to 6.75) & $0.86^{*}$ \\
Change in $\mathrm{SpO}_{2}$ & $-7.33(5.12)$ & $-3.83(4.90)$ & $\mathrm{FN}$ & $0.029 \dagger$ \\
Change in HR & $16.33(11.54)$ & $16.33(7.46)$ & $\mathrm{FN}$ & $0.93 \dagger$ \\
End Borg Dyspnoea & $3.72(1.90)$ & $3.86(1.87)$ & $\mathrm{FN}$ & $0.52 \ddagger$ \\
End Borg RPE & $11.36(2.29)$ & $11.00(2.86)$ & $\mathrm{FN}$ & $0.93 \ddagger$ \\
\hline
\end{tabular}

All data presented as mean (SD) or median (range).

*Paired t test.

†Wilcoxon signed rank test.

$\ddagger \chi^{2}$ test.

FN, failed normality test. 